\title{
Effectiveness of Photoprotective Strategies in Three Mixotrophic Planktonic Ciliate Species
}

\author{
Bettina Sonntag $1,2, * \mathbb{D}$ and Ruben Sommaruga ${ }^{2}(\mathbb{D}$ \\ 1 Research Department for Limnology, Mondsee, Leopold-Franzens-University of Innsbruck, \\ A-5310 Mondsee, Austria \\ 2 Department of Ecology, Leopold-Franzens-University of Innsbruck, A-6020 Innsbruck, Austria; \\ ruben.sommaruga@uibk.ac.at \\ * Correspondence: bettina.sonntag@uibk.ac.at; Tel.: +43-512-507-50243
}

Received: 15 May 2020; Accepted: 17 June 2020; Published: 20 June 2020

\begin{abstract}
Mixotrophic ciliate assemblages often prevail in summer in the surface layers of lakes. During this time, they are potentially exposed to damaging levels of incident solar ultraviolet radiation (UVR) and need efficient photoprotective mechanisms to minimize the damage. Herein, we tested the algal-bearing species of Pelagodileptus trachelioides, Stokesia vernalis, and Vorticella chlorellata for how they handled stress under exposure to the artificial sunlight spectrum (i.e., UV treatment), just photosynthetically active radiation (PAR), or in the dark (i.e., control). In addition to measurements of their survival, changes in behavior, shape, and whether dark or photoenzymatic repair (PER) mechanisms are present, we measured the concentration of UV-absorbing compounds (i.e., mycosporine-like amino acids). In contrast to the response in the PAR and dark treatments, sublethal effects were observed in all species when exposed to UVR. A wavelength-specific test for P. trachelioides revealed that UV-B was especially lethal. These results suggest that the photoprotective mechanisms found in these ciliates are not sufficient to allow for their survival directly at the surface and that, accordingly, they need to shift their position further down in the water column.
\end{abstract}

Keywords: algal-ciliate symbiosis; mycosporine-like amino acids; Pelagodileptus trachelioides; planktonic freshwater ciliates; Stokesia vernalis; Vorticella chlorellata

\section{Introduction}

It is well documented for many groups of organisms that exposure to solar radiation might cause severe direct and indirect negative effects [1,2]. Planktonic species are exposed, to a different extent, to solar ultraviolet radiation (UVR) which penetrates the water column. In subalpine lakes (i.e., located below the treeline), UVR is attenuated within the uppermost meters because chromophoric dissolved organic matter and phytoplankton absorb these short wavelengths $[3,4]$. To escape high UVR levels at the lake surface, some organisms such as zooplankton perform diel vertical migrations [5]. This adaptation is unknown for ciliates, and the species assemblage is believed to move along the water column and over the season according to food availability or water temperature [6-8]. Characteristically, during summer/autumn, mixotrophic ciliates that live in symbiosis with algal endosymbionts can be detected in the epilimnion of temperate lakes $[6,9,10]$. Such a mutualistic relationship between green algae and a ciliate host has different advantages for both partners, namely, the ciliate receives nutrients from its partners and the algae are transported into sunlit areas, ensuring a positive photosynthetic balance. In addition, the algae receive shelter from chloroviruses [11-13]. Another putative advantage of the algal-ciliate relationship, but less known, is photoprotection against UVR [14-16].

The short wavelengths of the sunlight spectrum in the ultraviolet range $(280-400 \mathrm{~nm})$ potentially cause damage to the DNA and other cell targets. In particular, the absorption of ultraviolet-B (UV-B; 
$280-315 \mathrm{~nm}$ ) and of ultraviolet-A (UV-A;315-400 $\mathrm{nm}$ ) radiation by DNA can damage its structure and can cause both mutagenic and lethal effects [17]. Consequently, organisms have evolved a variety of response mechanisms to prevent or repair damage from UVR, including physical avoidance by regulating their position in the water column, accumulation or synthesis of sunscreens (e.g., carotenoids and mycosporine-like amino acids), or repair of DNA damage (e.g., photoenzymatic repair and nucleotide excision repair $[2,18-20])$. Thus, UVR may not only have negative effects on organisms, but longer UV-A wavelengths and photosynthetically active radiation (PAR) can upregulate photoenzymatic repair (PER), where DNA damage is repaired with the enzyme photolyase. Alternatively, organisms may have a nucleotide excision repair mechanism ("dark repair"), where the damaged part of the DNA is removed and resynthesized $[17,21]$. PER and dark repair appear to be widespread among taxonomically diverse organisms and have been also identified in protists $[17,22-24]$. When all of these mechanisms are inefficient, diverse negative effects are observed. In protists, damage by UVR is known to lead to reduced motility and retarded division as well as a reduction in growth rates [25-29]. However, from the few studies available, for example, on ciliates, it is known that both damage by UVR and the presence of photoprotective mechanisms are species-specific [10,14-16,22,23,30-35]. For example, in laboratory experiments, Glaucoma sp. and Parauronema acutum recovered under photoreactive radiation or in the dark, whereas a Cyclidium species did not [22,23]. In some mixotrophic ciliates, two photoprotective mechanisms provided by the algal symbionts have been identified, namely, the synthesis of sunscreen compounds (i.e., mycosporine-like amino acids (MAAs)) and the self-shading effect given by the formation of dense algal layers inside the cell that prevent UVR from reaching the sensitive nuclear material [14-16]. Generally, MAAs are detected in a variety of organisms and they efficiently absorb UVR in the UV-B and the UV-A ranges between 309 and $362 \mathrm{~nm}[36,37]$. These secondary metabolites are considered efficient sunscreen compounds, and some of them also have antioxidant capacities as UVR is a source of oxidative stress [37]. In contrast to pigments, MAAs are colorless, water-soluble compounds and they are probably evenly distributed within the cytoplasm of an organism [38]. The biochemical pathways of their synthesis are still not yet fully identified in all taxa $[39,40]$. Therefore, it remains unclear if ciliates themselves are able to produce sunscreens or if they can only acquire them from an algal partner or can only extract them from their diet [14,34]. The internal shading of the nuclear material in ciliates through dense symbiotic algal layers seems to be an additional effective photoprotective mechanism $[10,15,16]$. This is important because not all ciliate species contain MAAs, but a well-directed internal allocation of algal symbionts regulates the photoprotective efficiency in non-planktonic ciliates such as Paramecium bursaria $[15,16]$.

Our hypothesis in this study is that, in the UVR-flooded zone of a lake, mixotrophic ciliates are well-adapted to this natural stress factor. Thus, we tested three representative species of the planktonic ciliate assemblage, i.e., Pelagodileptus trachelioides, Stokesia vernalis, and Vorticella chlorellata, for their photoprotective and recovery strategies. In experiments with freshly collected individuals, we ran a series of laboratory experiments under artificial radiation. We first assessed the ciliates' general survival under exposure to the full solar radiation spectrum and to PAR only against a dark control (experiment 1). Second and only for P. trachelioides, we identified the wavelengths responsible for potential damage and/or mortality and exposed the ciliates to UVR by the exclusion of certain UV-B and UV-A wavelengths with a set of long-pass cutoff filters (experiment 2). Third, we tested the availability of recovery strategies from UVR-induced impairments of the ciliates, including dark repair (all species) and PER (P. trachelioides) (experiment 3). Finally, we tested the survival of these ciliate species under extended UV exposure (experiment 1$)$.

\section{Materials and Methods}

\subsection{Ciliate Sampling}

Ciliates were collected in Piburgersee (PIB), an oligo-mesotrophic lake located in the Austrian Central Alps ( $\left.47^{\circ} 11^{\prime} \mathrm{N} 10^{\circ} 53^{\prime} \mathrm{E}\right)$. The lake is situated at $913 \mathrm{~m}$ above sea level and has a maximum 
depth of $24.6 \mathrm{~m}$. The lake is usually ice-covered from December through March/April. In PIB, UV-B radiation is completely attenuated after a depth of $3 \mathrm{~m}$ and UV-A is attenuated after a depth of ca. $7 \mathrm{~m}$ [10]. More information on UV transparency in PIB is given elsewhere [3].

From a previous study focused on PIB, we knew when the mixotrophic ciliate assemblage prevailed and the test species could be found [10]. Living ciliates for the experiments were collected by net tows in the uppermost $10 \mathrm{~m}$ of the water column with a 10- $\mu \mathrm{m}$ plankton net (Uwitec, Mondsee, Austria) on 31 August and 26 September 2011 for P. trachelioides, S. vernalis, and V. chlorellata, on 24 September 2012 for P. trachelioides, and on 1 and 17 October 2013 for P. trachelioides, S. vernalis, and V. chlorellata. Predatory zooplankton was excluded using a $250-\mu \mathrm{m}$ plankton net before the water was poured into 1-L plastic bottles. After being transported to the laboratory, the ciliate samples were kept at ambient lake water temperatures that were measured along a depth profile with a thermometer attached inside a 5-L Schindler-Patalas sampler $\left(16-17^{\circ} \mathrm{C}\right.$ on average in depths of $\left.0-10 \mathrm{~m}\right)$.

\subsection{Ciliate Handling Prior to Experiments}

We screened the concentrated plankton using a stereomicroscope (Olympus SZ 40, Vienna, Austria), and individuals were identified morphologically (Olympus BX50 microscope, Vienna, Austria) under differential interference contrast following the key literature of [41]. The three mixotrophic ciliate species under study could not be successfully kept and enriched in earlier long-term cultures. Consequently, the experiments were carried out with freshly collected specimens. For acclimation, single ciliates were transferred with drawn glass pipettes and placed into 12-well plates (Bio-One, Greiner, Kremsmünster, Austria) containing 0.2- $\mu \mathrm{m}$-filtered lake water (Minisart, Sartorius, Vienna, Austria). The experiments started the day after.

\subsection{Experimental Design}

\subsubsection{General Experimental Setup}

All experiments were run in a temperature-controlled walk-in chamber at $16-17^{\circ} \mathrm{C}$ in well plates without lids. As an irradiation source, we used four A-340 Q-Panel lamps $\left(8.60 \mathrm{~W} \mathrm{~m}^{-2} \mathrm{UV}-\mathrm{A}\right.$ and $2.47 \mathrm{~W} \mathrm{~m}^{-2}$ UV-B; Q-Lab, Saarbrücken, Germany) and two Osram Cool White lamps NL-T8 36W/640-1 (72 $\mu \mathrm{mol} \mathrm{m} \mathrm{m}^{-2} \mathrm{~s}^{-1}$ PAR; Osram, Vienna, Austria). This setup maintained over $4 \mathrm{~h}$ is able to simulate the daily UVR dose received at the lake's surface (air-water interface) in June at this latitude [29]. The ciliates were exposed (1) to the full spectrum of the two types of lamps (i.e., UV treatment), (2) to photosynthetically active radiation only (i.e., PAR treatment) by excluding the UVR with an Ultraphan-395 foil (UV-Opak, Digefra, Munich, Germany), and (3) to the dark (i.e., control) by wrapping the vessels with two layers of aluminum foil. The lamp spectrum weighted for the DNA Setlow action spectrum is given in [29].

Throughout all experiments, the ciliates were checked consecutively by eye under the stereomicroscope at 30-90 min intervals to record changes in numbers, shape, and movement. The number of individuals in the experimental wells was intentionally kept low, namely, five per well (P. trachelioides and S. vernalis) to be able to recognize any possible sublethal effects. As the epiplanktonic $V$. chlorellata was attached to colonies of Botryococcus braunii and it was not possible to successfully detach an adequate number from the algae, experiments were made to test only changes in shape and movement.

This general setup accompanied all three specific experiments (see below).

\subsubsection{Experiment $1(\exp 1)$ to Test the Ciliates' Overall Resistance to UVR}

Here, we tested the species-specific response to UVR and PAR, both against a dark control. Individual ciliates were monitored over an irradiation period of $4 \mathrm{~h}$ (i.e., the natural daily dose at the surface for this geographical location) and of $7.5 \mathrm{~h}$ (i.e., an increased dose). This experiment was repeated twice each with V. chlorellata and S. vernalis (in 2011 and 2013) and five times with 
P. trachelioides (in 2011, 2012, and 2013) as well as in four replicates containing five individuals each (except for $V$. chlorellata; see explanation above). To test for variability under the different exposure conditions, in 2011, we once quantified the MAAs for S. vernalis and P. trachelioides following the protocol of [14]. For V. chlorellata, MAAs could not be determined because the ciliates could not be separated from their algal attachment sites (that probably also contained MAAs).

\subsubsection{Experiment 2 (exp 2) to Identify the UVR Wavelength-Specific Response of $P$. trachelioides}

To identify changes in the survival, movement, and shape of $P$. trachelioides at specific wavelengths, we exposed the ciliates under a series of long-pass cutoff quartz-glass filters (Andover Corporation, Salem, NH). The filters let UV-B and UV-A pass above specific wavelengths, i.e., 280, 295, 305, 320, 335, 345 , and $360 \mathrm{~nm}$. Due to their size of $50 \times 50 \mathrm{~mm}$ and their $3 \mathrm{~mm}$ thickness, one filter covered four wells of a 12-well plate at once (i.e., four replicates at five individuals each). To keep offside irradiation during experiments, the rest of each plate was covered with black foil. Exp 2 was carried out three times with individuals from 2011 (once) and 2012 (twice) and ran over $7.5 \mathrm{~h}$ in total. We calculated the transmission of each cutoff filter from the measured UV spectrum and integrated the dose rate over time for the UV-B and UV-A wavelength-specific ranges (Table S1).

2.3.4. Experiment 3 (exp 3) to Test for the Ciliates' Recovery Potential by “Dark Repair" (All Species) and PER (P. trachelioides)

In exp 3, we aimed to identify the recovery processes for curing the sublethal effects caused by previous exposure (exp 1 and exp 2). We recorded survival, behavioral, and morphological changes and symbiont dislocation.

To test for dark repair, survivors from exp 1 and exp 2 were kept at ambient temperatures in the dark for $12 \mathrm{~h}$, and subsequently, they were maintained under light/dark conditions (16:8 h; $80 \mathrm{mmol} \mathrm{m}^{-2} \mathrm{~s}^{-1}$ PAR, $\left.0.10 \mathrm{~W} \mathrm{~m}^{-2} \mathrm{UV}-\mathrm{A}\right)$. The dark repair approach subsequently followed exp 1 and $\exp 2$ with any of the three species involved.

To test for PER, individuals of $P$. trachelioides were exposed to UVR (two parallel sets at once) and one dark control similar to exp 1 with the following modifications: after $4 \mathrm{~h}$ of exposure, one UV set was covered with Ultraphan-395 foil to cut off the UVR wavelengths (hereafter, UVR_4h) and the second set was covered after $6 \mathrm{~h}$ (hereafter, UVR_6h). After the respective UV treatments (i.e., UVR_4 $\mathrm{h}$ or UVR_6 h) the ciliates were exposed to photo-repairing light, i.e., 3.5 and $5.5 \mathrm{~h}$, accordingly. The PER exp 3 was done twice (i.e., in 2011 in triplicates with nine individuals each and in 2012 in 12 replicates with five individuals each).

\subsection{Statistical Analyses}

To test for significant differences between the UV and PAR treatments against the control in exp 1-3 at a 95\% significance level, we applied a nonparametric one-way ANOVA on Ranks (Kruskal-Wallis test) with Dunn's post hoc test. All analyses were conducted with the program SigmaPlot version 12.5. Data of the same experiment and ciliate were pooled.

\section{Results}

For the three ciliates tested, we identified species-specific responses regarding their photoprotection strategies as described in detail below (Figure 1).

\subsection{Stokesia Vernalis}

No significant mortality occurred in any of the three treatments, neither over $4 \mathrm{~h}$ (i.e., natural daily dose) nor over $7.5 \mathrm{~h}$ in $\exp 1(p>0.05)$. Moreover, no abnormal swimming behavior, changes in shape, or symbiont disarrangement were detected (B.S. personal observation). After $48 \mathrm{~h}(\exp 3)$, about $20 \%$ of survivors were left over after the UV treatment $(p<0.05)$ in contrast to PAR and the control ( $p>0.05$; Figure 2). After exposure (exp 1), the concentration of MAAs was highest in the UV 
treatment, followed by PAR and then the control. Shinorine was the dominant MAA ( $99 \%$ of the total amount of MAAs) after all three experimental treatments, and asterina-330, palythene, and usujirene were only found in traces (Table 1).
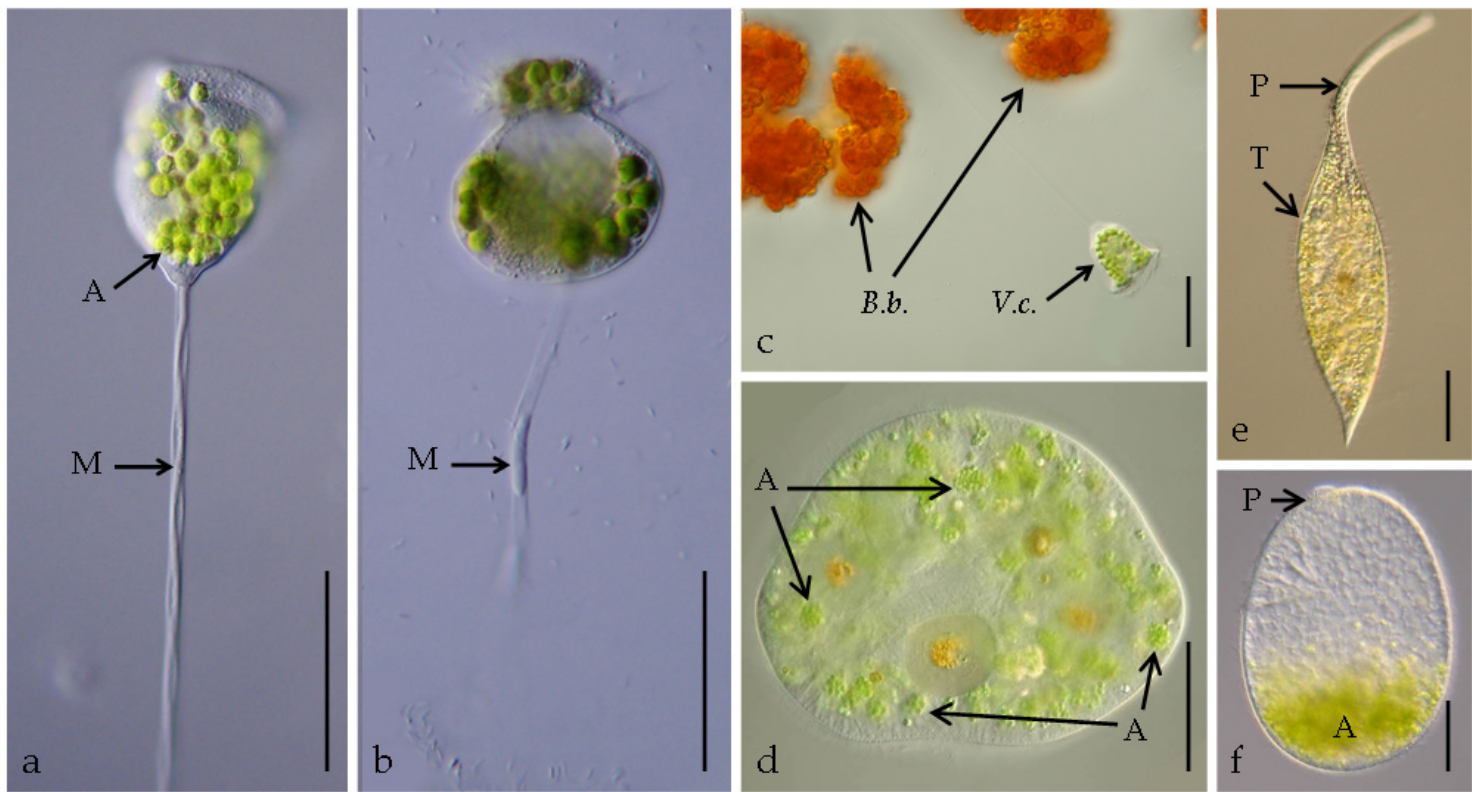

Figure 1. Living individuals of Vorticella chlorellata $(\mathbf{a}-\mathbf{c})$, Stokesia vernalis (d), and Pelagodileptus trachelioides (e,f): (a) Overall view of an intact stalked individual after photosynthetically active radiation (PAR) (experiment (exp) 1); (b) unusual globular appearance of the cell $48 \mathrm{~h}$ after the UV treatment (exp 3), with the distorted myoneme (stalk protein) visible (arrow); (c) V. chlorellata attached to colonies of Botryococcus braunii (d), showing the right lateral view, where the arrows point out to the unique "packages" of algal symbionts; (e) total view, showing the prominent proboscis and trunk; and (f) left lateral view of an individual without proboscis after $6.5 \mathrm{~h}$ under ultraviolet radiation (UVR) (exp 1 ), where the arrow points to the stump of the proboscis left over, the symbionts were accumulated in the posterior cell portion. A, algal symbionts; B.b., colonies of Botryococcus braunii; M, myoneme of the stalk; P, proboscis; T, trunk, V.c., individual of V. chlorellata. Scale bars: $50 \mu \mathrm{m}(\mathbf{a}-\mathbf{e})$ and $10 \mu \mathrm{m}(\mathbf{f})$.

Table 1. Concentrations of mycosporine-like amino acids $\left(10^{-5} \mu \mathrm{g} \mu \mathrm{g}^{-1}\right.$ ciliate dry weight $)$ in individuals of Stokesia vernalis $(n=14-16)$ and Pelagodileptus trachelioides $(n=48-54)$ collected after exposure to UVR and PAR and in the control (exp 1). Traces: concentrations $<1 \%$ of the total. Percentages in brackets $=$ $\%$ of the concentration of a specific mycosporine-like amino acid (MAA) in the total concentration of MAAs detected.

\begin{tabular}{cccccccc}
\hline Ciliate Species & Sample & Total & Shinorine & Palythine & Asterina-330 & Palythene & Usujirene \\
\hline S. vernalis & UVR & 1.86 & $1.86(99 \%)^{1}$ & - & - & Traces & Traces \\
& PAR & 1.60 & $1.60(99 \%)^{1}$ & - & Traces & Traces & Traces \\
& Control & 1.00 & $1.00(99 \%)^{1}$ & - & - & Traces & - \\
P. trachelioides & UVR & 3.16 & $2.89(91 \%)^{1}$ & $0.27(9 \%)^{2}$ & Traces & Traces \\
& PAR & 2.49 & $2.22(89 \%)^{1}$ & $0.27(11 \%)^{2}$ & Traces & Traces \\
& Control & 2.58 & $2.38(92 \%)$ & $0.20(8 \%)$ & - & Traces & Traces \\
\hline
\end{tabular}

${ }^{1}$ Mainly shinorine with proportions of porphyra-334 (peaks in chromatogram not distinctly separated). ${ }^{2}$ Peaks in chromatogram not distinctly separated in either palythine or asterina-330. 


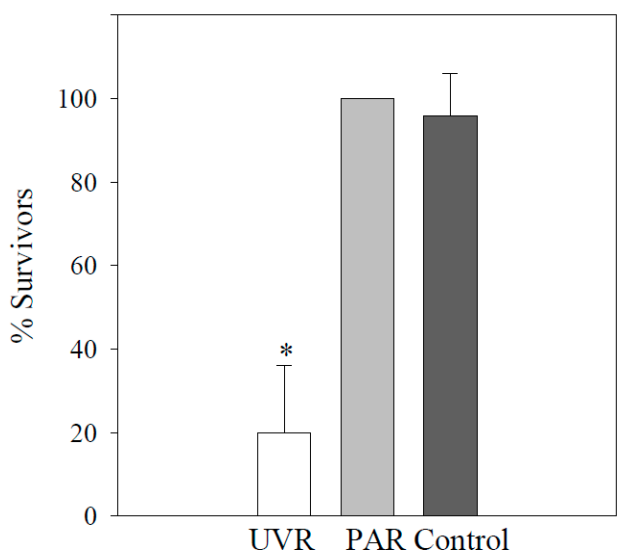

Figure 2. Surviving individuals ( $\% \pm \mathrm{std}$ ) of Stokesia vernalis after $48 \mathrm{~h}$ after $\exp 3$ (follow-up on $\exp 2$ ): $n=4$ replicate wells containing five individuals each; * indicates a significant difference between the UV treatment and the control $(p<0.05)$.

\subsection{Vorticella Chlorellata}

In the PAR treatment and in the control, no changes in the ciliates' appearance and behavior were recorded (exp 1; Figure 1a). During UV exposure, some individuals had broken myonemes (i.e., stalk proteins) from $6 \mathrm{~h}$ onward (Figure 1b). After $48 \mathrm{~h}$, their stalks did not contract any more, the adoral membranelles did not filter anymore, and finally, the ciliates died.

\subsection{Pelagodileptus trachelioides}

All individuals tested survived $7.5 \mathrm{~h}$ of exposure in any treatment as well as in the control (exp 1; $p>0.05)$. After the dark repair period (exp 3), significant mortalities were observed in individuals from the UV treatment and at 280, 295, and $305 \mathrm{~nm}(p \leq 0.001)$ in contrast to $320,335,345$, and $360 \mathrm{~nm}$, PAR, and the control ( $p>0.05$; Figure 3a). Individuals already moved slower than usual after $2.5 \mathrm{~h}$ in the UV treatment and $280 \mathrm{~nm}$, after $3.5 \mathrm{~h}$ in 295 and $305 \mathrm{~nm}$, and after $5.5 \mathrm{~h}$ in $320 \mathrm{~nm}$ but not in the other treatments (B.S. personal observation). Morphological alterations, such as a spherical appearance with a reduced trunk and a reduction in proboscis length (Figure 1f), were observed in the UV treatment and at 280, 295, and $305 \mathrm{~nm}$ after $7.5 \mathrm{~h}$ in approximately $10 \%$ of the individuals but not in all other treatments (i.e., $\exp 1$ and exp 2). A symbiont accumulation in the posterior cell portion of P. trachelioides was observed after $4.5 \mathrm{~h}$ and later only in the UV-B treatments (i.e., $\exp 1$ and $\exp 2$ ).

In the PER exp 3, all ciliates survived the exposure over $4 \mathrm{~h}$ (UVR_4h), the PER period (5.5 h), and the dark period ( $12.5 \mathrm{~h} ; p>0.05$; Figure $3 \mathrm{~b}$ and Figure S1). Approximately $15-20 \%$ of the individuals survived three weeks. In the UVR_6h treatment, survival significantly decreased after the dark period (12.5 h; $p \leq 0.001$; Figure $3 \mathrm{~b}$ ), accompanied by decreased swimming activity and dislocated symbionts, seen after $9.5 \mathrm{~h}$ in $24 \%$ of the survivors (B.S. personal observation). No individual from the UVR_6h treatment was sustained $48 \mathrm{~h}$ after exposure.

Among the MAAs detected, shinorine was the dominant one (approximately $90 \%$ ) in all three treatments, followed by palythine and asterina-330, and then traces of palythene and usujirene (Table 1). The concentration of MAAs decreased from the UV treatment to the dark control. 


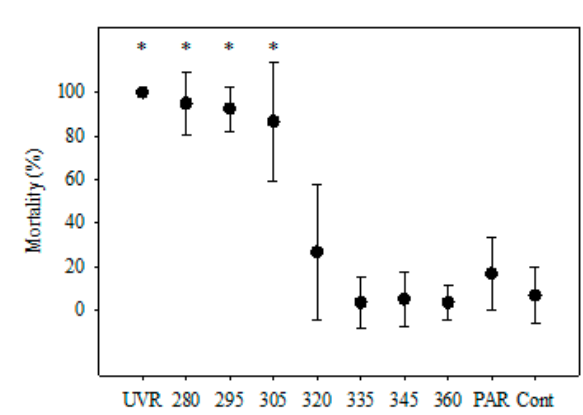

(a)

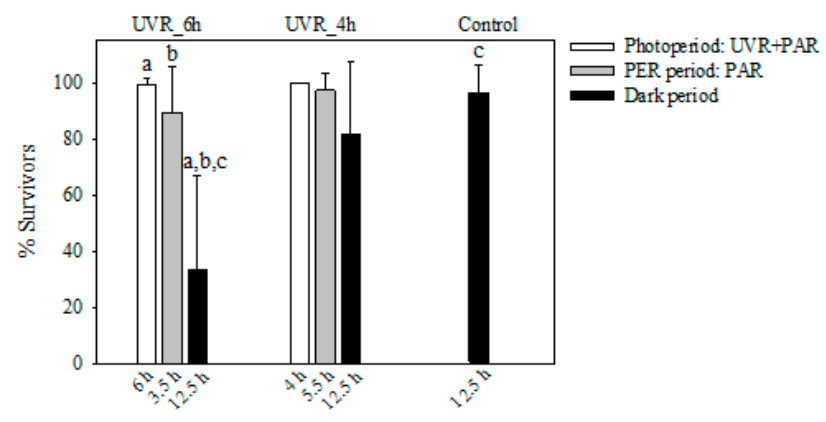

(b)

Figure 3. (a) Mortality ( $\% \pm$ std) of Pelagodileptus trachelioides $24 \mathrm{~h}$ after T0 (exp 1 and 2): The experimental treatments were UVR, 280, 295, 305, 320, 335, 345, and $360 \mathrm{~nm}$, PAR, and control (Cont). Data of three individual experiments were pooled ( $n=60$ for all treatments, except for 280 and $295 \mathrm{~nm}$ with $n=40)$. * indicates significant mortality against the control $(p \leq 0.001)$. (b) Means of the surviving individuals ( $\% \pm$ std) of $P$. trachelioides after experimental exposure to UVR_4h (without UVR after $4 \mathrm{~h}$ ) and UVR_6h (without UVR after $6 \mathrm{~h}$ ) and in the control (exp 3). X-axis: duration (h) of the UVR + PAR period, the photoenzymatic repair (PER) period (without UVR), and the dark period. $a, b$, and $c$ indicate significant mortality $(p<0.05)$ between treatments.

\section{Discussion}

Autecological data on planktonic ciliate species are scarce, and almost nothing is known about their strategies to cope with potentially damaging UVR (see the review in [41]). The ciliates tested here commonly occur in subalpine lakes, and they are members of the mixotrophic assemblage found in Piburgersee $[10,41,42]$. Considering that, in this lake, UV-B radiation is completely attenuated after $3 \mathrm{~m}$ and UV-A after approximately $7 \mathrm{~m}$, effective photoprotective strategies appear to be essential for the survival of plankton [10]. Interestingly, the ciliates tested here were obviously not as tolerant to solar radiation conditions as we assumed, and the effectiveness of the UV photoprotective strategies tested was unexpectedly low.

Certainly, under the experimental conditions tested here, an escape reaction away from UVR was not possible because the ciliates were "trapped" in the shallow wells. Therefore, our approach does not necessarily reflect the in situ situation but, instead, tested how different species reacted to the same controlled experimental manipulation. In fact, the results from a one-year seasonal study in Piburgersee showed that $P$. trachelioides, $V$. chlorellata, and S. vernalis dwell in the uppermost meters during summer (Figure S2).

In a previous study on the overall resistance to UVR of the ciliate summer community from Piburgersee, $V$. chlorellata was the only ciliate species that survived exposure under UVR [10]. The authors concluded that, probably because of the high MAA concentrations and the presence of densely packed algal symbionts, UVR was hindered from reaching sensitive cell targets such as the nuclei [10]. In the present experiments, V. chlorellata again first appeared to be resistant to UVR but, finally, all individuals died. The possible sublethal effects were probably masked in the previous study, where the ciliates were preserved right at the end of the experiment [10]. Another factor that probably allows $V$. chlorellata to live directly at the surface of Piburgersee is its association with B. braunii (Figure 1c). These planktonic algae form large colonies that can even be recognized by the naked eye. As the algal colonies serve as attachment sites for $V$. chlorellata, we argue that shading from incident solar radiation by the (probably mutualistic) algal partner is important.

For S. vernalis, physical shading of the nuclei through algal symbionts is unlikely because they are uniquely arranged in a variable number of "packages" and because aposymbiotic individuals naturally occur (Figure 1d; [41,43]). Accordingly, the UV-screening efficiency by self-shading is expected to be significantly lower in $S$. vernalis than in other mixotrophic species, such as $V$. chlorellata or P. bursaria $[10,15,16]$. MAA analyses of $S$. vernalis from PIB revealed that these compounds were 
only detected in very low concentrations when they were there (Table $1 ;$ [14]). The synthesis of MAAs per se is energetically costly, and the concentrations required for individual photoprotection were probably too low to tolerate the UVR dose tested here. Although MAAs are considered efficient sunscreen compounds, it remains unknown what concentration is needed to provide an efficient protection in ciliates, although in general, the larger the cell diameter, the higher the potential sunscreen efficiency [38]. Therefore, we can only speculate that the MAA concentrations might have either been too low for efficient UVR screening or that they may have different functions other than photoprotection.

Out of the three species tested here, $P$. trachelioides was the most sensitive to UVR, especially to UV-B (Figure 1f, Figure 3a,b and Figure S1). This was unexpected because, in this large dileptid ciliate of up to $>1 \mathrm{~mm}$ in length, we found the highest concentration of MAAs among the three tested species (Table 1) as well as the existence of numerous algal symbionts [14]. Nevertheless, the existence of a PER in P. trachelioides indicates the potential to counteract UVR damage (Figure 3b). Our results add to previous reports of the existence of PER in the ciliates Glaucoma sp. and P. acutum as a major strategy in UV-B tolerance [22,23].

Physical damage, including the easy loss of the prominent proboscis of $P$. trachelioides through mechanical disturbance (e.g., by a pipette), has been observed earlier $[44,45]$, and here, we found that UVR contributed to significant length reductions (Figure $1 \mathrm{f}$ and Figure S1). The proboscis is necessary for feeding and swimming and can be regenerated within several hours to almost double the trunk length, especially when the ciliates remained undisturbed (Figure 1e; [44,45]). Although several studies on the regeneration of surgically amputated mouthparts in dileptids and stentorids have been done in the past, unfortunately, none of them ever mentioned a reason behind losing and regenerating a proboscis or trunk [46-51].

Algal symbiont accumulation in the posterior cell region has been reported for P. trachelioides, though from the scientific literature, it is unclear what caused the dislocation (Figure 1f; [45,52,53]). Some authors observed this phenomenon before cytolysis, for instance, Krainer [53] and Butkay [45] found such individuals already in their original habitats. Butkay [45] assumed that increasing water temperature and/or an escape reaction away from an irradiation source may have been the reasons. Symbiont dislocation into the posterior cell region only attains efficient photoprotection when this cell region is simultaneously directed toward the radiation source, providing a kind of "umbrella" that actively shades the nuclei. This phenomenon has been observed in P. bursaria, and it is reversible depending on the level of UV exposure. Thus, when UVR is excluded, the symbionts are immediately evenly distributed inside the cell again $[15,16]$. Although it is unknown what exactly triggers the dislocation in P. trachelioides, our observations suggest that UVR is involved. Because all three species were obviously stressed by UVR, the photoprotective role of the symbionts is called into question. However, the symbionts themselves might also have been negatively impacted by UVR, although this was not tested here.

\section{Conclusions}

The three ciliate species tested here for their photoprotective strategies are common members of a mixotrophic assemblage that frequently occur in temperate lakes in summer/autumn. These planktonic ciliates were equipped with MAAs and numerous algal symbionts that suggest efficient protection from UVR. However, none of the ciliates survived under simulated UVR conditions similar to natural doses found at the lake surface. Considering that UVR is rapidly attenuated in the water column, the photoprotection level that these species have is probably enough for survival. However, an acclimation to higher doses does not seem feasible and is energetically too costly in the short term. Based on our results, we argue that the ciliates tested here need to actively shift their position along the depth (UV) gradient and to rely on vertical migration in the water column to escape the highest incident solar radiation levels around solar noon. Future studies on the photoprotective strategies of other mixotrophic ciliate species will shed more light on the role of MAAs and shading by algal symbionts under in situ conditions. 
Supplementary Materials: The following are available online at http://www.mdpi.com/1424-2818/12/6/252/s1, Table S1: UV-A and UV-B doses $\left(\mathrm{kJ} \mathrm{m}^{-2}\right)$ over the experimental period, Figure S1: Scheme of the morphological changes of Pelagodileptus trachelioides observed under irradiation conditions in the photoenzymatic repair experiment, Figure S2: Seasonal and spatial occurrence of Pelagodileptus trachelioides, Vorticella chlorellata, and Stokesia vernalis in Piburgersee in 2004-2005 [54].

Author Contributions: Conceptualization, B.S.; methodology, B.S. and R.S.; investigation, B.S.; data curation, B.S. and R.S.; writing-original draft preparation, B.S.; writing—review and editing, R.S.; project administration, B.S. and R.S; funding acquisition, B.S. and R.S. All authors have read and agreed to the published version of the manuscript.

Funding: This research was funded by the Austrian Science Fund FWF, grant numbers P21013-B03, P28333-B25, and P16559-B06. Open Access Funding by the Austrian Science Fund (FWF).

Acknowledgments: The authors thank Josef Franzoi, Barbara Kammerlander, Gry Larsen, Salvador Morales-Gomez, and Monika Summerer for help with sampling and in the laboratory. The authors also thank Michael Butkay for providing unpublished material and helpful comments on Pelagodileptus trachelioides. The authors express their gratitude to the three anonymous reviewers who suggested valuable and critical suggestions and comments on an earlier version of the manuscript. Open Access Funding by the Austrian Science Fund (FWF).

Conflicts of Interest: The authors declare no conflict of interest.

\section{References}

1. Sommaruga, R. The role of solar UV radiation in the ecology of alpine lakes. Photochem. Photobiol. 2001, 62, 35-42. [CrossRef]

2. Rautio, M.; Tartarotti, B. UV radiation and freshwater zooplankton: Damage, protection and recovery. Freshwater Rev. 2010, 3, 105-131. [CrossRef] [PubMed]

3. Laurion, I.; Ventura, M.; Catalan, J.; Psenner, R.; Sommaruga, R. Attenuation of ultraviolet radiation in mountain lakes: Factors controlling the among- and within-lake variability. Limnol. Oceanogr. 2000, 45, 1274-1288. [CrossRef]

4. Rose, K.C.; Williamson, C.E.; Saros, J.E.; Sommaruga, R.; Fischer, J.M. Differences in UV transparency and thermal structure between alpine and subalpine lakes: Implications for organisms. Photochem. Photobiol. Sci. 2009, 8, 1244-1256. [CrossRef] [PubMed]

5. Tartarotti, B.; Cabrera, S.; Psenner, R.; Sommaruga, R. Survivorship of Cyclops abyssorum tatricus (Cyclopoida, Copepoda) and Boeckella gracilipes (Calanoida, Copepoda) under ambient levels of solar UVB radiation in two high-mountain lakes. J. Plankton Res. 1999, 21, 549-560. [CrossRef]

6. Sonntag, B.; Posch, T.; Klammer, S.; Teubner, K.; Psenner, R. Phagotrophic ciliates and flagellates in an oligotrophic deep alpine lake: Contrasting variability with seasons and depths. Aquat. Microb. Ecol. 2006, 43, 193-207. [CrossRef]

7. Müller, H.; Schöne, A.; Pinto-Coelho, R.M.; Schweizer, A.; Weisse, T. Seasonal succession of ciliates in Lake Constance. Microb. Ecol. 1991, 21, 119-138. [CrossRef]

8. Müller, H.; Geller, W.; Schöne, A. Pelagic ciliates in Lake Constance: Comparison of epilimnion and hypolimnion. Verh. Int. Verein. Limnol. 1991, 24, 846-849. [CrossRef]

9. Carrias, J.F.; Amblard, C.; Bourdier, G. Seasonal dynamics and vertical distribution of planktonic ciliates and their relationship to microbial food resources in the oligo-mesotrophic Lake Pavin. Arch. Hydrobiol. 1998, 143, 227-255. [CrossRef]

10. Sonntag, B.; Summerer, M.; Sommaruga, R. Are freshwater mixotrophic ciliates less sensitive to solar UV radiation than heterotrophic ones? J. Euk. Microbiol. 2011, 58, 196-202. [CrossRef]

11. Reisser, W. Studies on the ecophysiology of endocytobiotic associations of ciliates and algae. II. Potential features of adaptation of symbiotic and free-living Chlorella spp. to the endocytobiotic habitat formed by Paramecium bursaria. Endocyt. Cell Res. 1987, 4, 317-329.

12. Yamada, T.; Onimatsu, H.; Van Etten, J.L. Chlorella viruses. Adv Virus Res. 2006, 66, 293-336. [CrossRef] [PubMed]

13. Pröschold, T.; Darienko, T.; Silva, P.C.; Reisser, W.; Krienitz, L. The systematics of "Zoochlorella" revisited employing an integrative approach. Environ. Microbiol. 2011, 13, 350-364. [CrossRef] [PubMed]

14. Sonntag, B.; Summerer, M.; Sommaruga, R. Sources of mycosporine-like amino acids in planktonic Chlorella-bearing ciliates (Ciliophora). Freshwater Biol. 2007, 52, 1476-1485. [CrossRef] 
15. Summerer, M.; Sonntag, B.; Hörtnagl, P.; Sommaruga, R. Symbiotic ciliates receive protection against UV damage from their algae: A test with Paramecium bursaria and Chlorella. Protist 2009, 160, 233-243. [CrossRef]

16. Sommaruga, R.; Sonntag, B. Photobiological aspects of the mutualistic association between Paramecium bursaria and Chlorella. In Microbiology Monographs: Endosymbionts of Paramecium; Fujishima, M., Ed.; Springer: Berlin, Germany, 2009; Volume 12, pp. 111-130. [CrossRef]

17. Mitchell, D.L.; Karentz, D. The induction and repair of DNA photodamage in the environment. In Environmental UV photobiology; Young, A.R., Björn, L.O., Moan, J., Nultsch, W., Eds.; Plenum Press: New York, NY, USA, 1993; pp. 345-377.

18. Laurion, I.; Lami, A.; Sommaruga, R. Distribution of mycosporine-like amino acids and photoprotective carotenoids among freshwater phytoplankton assemblages. Aquat. Microb. Ecol. 2002, 26, 283-294. [CrossRef]

19. Slaveykova, V.; Sonntag, B.; Gutiérrez, J.C. Stress and protists: No life without stress. Eur. J. Protistol. 2016, 55, 39-49. [CrossRef]

20. Hylander, S. Mycosporine-like amino acids (MAAs) in zooplankton. Mar. Drugs 2020, 18, 72. [CrossRef]

21. Karentz, D. Ultraviolet tolerance mechanisms in Antarctic marine organisms. In Ultraviolet Radiation in Antarctica: Measurements and Biological Effects; Weiler, C.S., Panhale, P.A., Eds.; American Geophysical Union: Washington, DC, USA, 1994; pp. 93-110.

22. Sanders, R.W.; Macaluso, A.L.; Sardina, T.J.; Mitchell, D.L. Photoreactivation in two freshwater ciliates: Differential responses to variations in UV-B flux and temperature. Aquat. Microb. Ecol. 2005, 40, $283-292$. [CrossRef]

23. Hamsher, S.E.; Cheng, Y.T.S.; Sanders, R.W. Effects of temperature and photorepair radiation on a marine ciliate exposed to UVB radiation. J. Euk. Microbiol. 2018, 65, 458-467. [CrossRef]

24. Smith-Sonneborn, J. DNA repair and longevity assurance in Paramecium tetraurelia. Science 1979, 203, 1115-1117. [CrossRef] [PubMed]

25. Giese, A.C. Differential susceptibility of a number of protozoans to ultraviolet radiations. J. Cell Comp. Physiol. 1938, 12, 129-138. [CrossRef]

26. Giese, A.C. The ultraviolet action spectrum form retardation of division of Paramecium. J. Cell Comp. Physiol. 1945, 26, 47-55. [CrossRef]

27. Giese, A.C.; McCaw, B.; Cornell, R. Retardation of division of three ciliates by intermittent and continuous ultraviolet radiations at different temperatures. J. Gen. Physiol. 1963, 46, 1095-1108. [CrossRef] [PubMed]

28. Häder, D.P.; Häder, M.A. Effects of solar radiation on motility in: Stentor coeruleus. Photochem. Photobiol. 1991, 54, 423-428. [CrossRef]

29. Sommaruga, R.; Oberleiter, A.; Psenner, R. Effect of UV Radiation on the bacterivory of a heterotrophic nanoflagellate. Appl. Environ. Microbiol. 1996, 62, 4395-4400. [CrossRef]

30. Di Guiseppe, G.; Cervia, D.; Vallesi, A. Divergences in the response to ultraviolet radiation between polar and non-polar ciliated protozoa. Microb. Ecol. 2012, 63, 334-338. [CrossRef]

31. Kammerlander, B.; Tartarotti, B.; Sonntag, B. The impact of UV radiation on Paramecium populations from alpine lakes. J. Euk. Microbiol. 2018, 65, 250-254. [CrossRef]

32. Sommaruga, R.; Buma, A.G.J. UV-induced cell damage is species-specific among aquatic phagotrophic protists. J. Euk. Microbiol. 2000, 47, 450-455. [CrossRef]

33. Sonntag, B.; Summerer, M.; Sommaruga, R. Factors involved in the distribution pattern of ciliates in the water column of a transparent alpine lake. J. Plankton Res. 2011, 33, 541-546. [CrossRef]

34. Sonntag, B.; Kammerlander, B.; Summerer, M. Bioaccumulation of ultraviolet sunscreen compounds (mycosporine-like amino acids) by the heterotrophic freshwater ciliate Bursaridium living in alpine lakes. Inland Waters 2017, 7, 55-64. [CrossRef] [PubMed]

35. Wickham, S.; Carstens, M. Effects of ultraviolet-B radiation on two arctic microbial food webs. Aquat. Microb. Ecol. 1998, 16, 163-171. [CrossRef]

36. Carreto, J.I.; Carignan, M.O. Mycosporine-like amino acids: Relevant secondary metabolites. Chemical and ecological aspects. Mar. Drugs 2010, 9, 387-446. [CrossRef] [PubMed]

37. Wada, N.; Sakamoto, T.; Matsugo, S. Mycosporine-like amino acids and their derivates as natural antioxidants. Antioxidants 2015, 4, 603-646. [CrossRef] [PubMed]

38. Garcia-Pichel, F. A model for internal self-shading in planktonic organisms and its implications for the usefulness of ultraviolet sunscreens. Limnol. Oceanogr. 1994, 39, 1704-1717. [CrossRef] 
39. Lalegerie, F.; Stiger-Pouvreau, V.; Connan, S. Temporal variation in pigment and mycosporine-like amino acid composition of the red macroalga Palmaria palmata from Brittany (France): Hypothesis on the MAA biosynthesis pathway under high irradiance. J. Appl. Phycol. 2020. [CrossRef]

40. Pathak, J.; Ahmed, H.; Rajneesh Singh, S.P.; Häder, D.P.; Sinha, R.P. Genetic regulation of scytonemin and micosporine-like amino acids (MAAs) biosynthesis in cyanobacteria. Plant Gene 2019, 17, 100172. [CrossRef]

41. Foissner, W.; Berger, H.; Schaumburg, J. Identification and Ecology of Limnetic Plankton Ciliates; Bayer, Landesamt für Wasserwirtschaft: Munich, Germany, 1999; Volume 3/99, pp. 1-793.

42. Vd'ačný, P.; Foissner, W. Monograph of the dileptids (Protista, Ciliophora, Rhynchostomatia). Denisia 2012, 31, 1-529.

43. Wenrich, H.D. Observations of some freshwater ciliates (Protozoa). I. Teuthophrys trisulca Chatton and de Beauchamp and Stokesia vernalis n.g., n. sp. Trans. Am. Microsc. Soc. 1929, 48, 221-241.

44. Packroff, G.; Wilbert, N. Taxonomische Studien über die Ciliatenfauna (Protozoa, Ciliophora) der Eifelmaare. Arch. Protistenkd. 1991, 140, 121-139. [CrossRef]

45. Butkay, M. Beobachtungen an Pelagodileptus trachelioides (Ciliophora). Lauterbornia 2004, 49, 129-139.

46. Golińska, K. Effect of puromycin on regeneration processes in Dileptus anatinus Golinska 1971. Acta Protozool. 1974, 12, 289-360.

47. Golińska, K. The course of in situ remodeling of injured mouthparts in Dileptus (Ciliata, Gymnostomata). Acta Protozool. 1978, 17, 47-67.

48. Golińska, K. Assessment of cell proportions during regeneration of Dileptus anser (Ciliata). Wilhelm Roux's Archives 1979, 187, 307-321. [CrossRef] [PubMed]

49. Golińska, K.; Kink, J. The regrowth of oral structures in Dileptus cygnus after partial excision. Acta Protozool. 1975, 15, 143-163.

50. Tatar, V. The Biology of Stentor; Pergamon Press Ltd.: Oxford, GB, USA, 1961; pp. 1-413.

51. Wei, W.; Jiang, C.; Yang, W.; Miao, W.; Xiong, J. Proteomic identification and expression of oral apparatus constituents in cell regeneration of giant ciliate Stentor coeruleus (strain WHEL). Gene 2020, 743, 144624. [CrossRef]

52. Dragesco, J. Ciliés libres de Thonon et ses environs. Protistologica 1966, 2, 59-95.

53. Krainer, K.-H. Alpha-Taxonomie und Ökologie Neuer Sowie Mehrerer Wenig Bekannter Pelagischer Ciliaten (Protozoa: Ciliphora aus den Klassen Kinetofragminophora, Oligohymenophora, Polyhymenophora) Einiger Grundwasserbaggerteiche des Nördlichen Leibnitzer Feldes (Steiermark, Österreich). Ph.D. Thesis, University of Graz, Graz, Austria, 1988.

54. Skibbe, O. An improved quantitative protargol stain for ciliates and other planktonic protists. Arch. Hydrobiol. 1994, 130, 339-347.

(C) 2020 by the authors. Licensee MDPI, Basel, Switzerland. This article is an open access article distributed under the terms and conditions of the Creative Commons Attribution (CC BY) license (http://creativecommons.org/licenses/by/4.0/). 